\title{
DESAIN KURIKULUM PENDIDIKAN AGAMA KRISTEN UNTUK IBADAH YANG BERORIENTASI PADA ETOS KERJA KRISTEN BAGI PEGAWAI PEMERINTAH DI BALAI KOTA PROPINSI DKI JAKARTA
}

\author{
Solmeriana Sinaga \\ sinaga.solmeriana@gmail.com \\ Demsy Jura \\ Universitas Kristen Indonesia \\ demsy.jura@uki.ac.id
}

\begin{abstract}
Abstrak
Kurikulum merupakan sebuah alat yang digunakan untuk melihat sejauh mana proses pembelajaran yang mampu untuk memenuhi kebutuhan peserta didik. Kurikulum tidak terlepas dari sebuah proses pembelajaran serta pengalaman dalam belajar itu sendiri. Dalam hal ini kurikulum tidak hanya diperlukan dalam pendidikan formal, namun dalam pendidikan informal sekalipun sangat dibutuhkan, sebab kurikulum juga merupakan pondasi yang kuat dalam sebuah pembelajaran di dunia pendidikan.

Penelitian ini bertujuan untuk mendesain kurikulum pendidikan agama Kristen untuk ibadah yang berorientasi pada etos kerja Kristen bagi pegawai pemerintah di Balai Kota Propinsi DKI Jakarta. Penelitian menggunakan metode deskriptif kualitatif. Sampel ditetapkan menggunakan model sampel bertujuan (purposive sampling). Informan dalam penelitian ini berjumlah 10 orang pegawai Kristen yang terdiri pengurus ibadah dan peserta ibadah. Data dikumpulkan dengan menggunakan teknik wawancara, sedangkan teknik analisis data menggunakan model deskripsi analisis.

Dari hasil penelitian ini ditemukan bahwa pemahaman para pengurus tentang kurikulum pendidikan agama Kristen sudah memadai dan pemahaman pengurus ibadah dan peserta ibadah tentang etos kerja Kristen dan ibadah juga sudah memadai. Penelitian ini dapat memberi gambaran tentang desain kurikulum pendidikan agama Kristen untuk ibadah yang berorientasi dalam meningkatkan etos kerja Kristen. Hasil temuan penulis ialah kurikulum pendidikan agama Kristen sangat penting untuk diterapkan dalam ibadah yang berlangsung setiap hari Jumat pada pemerintah di Balai Kota Propinsi DKI Jakarta.

Kata Kunci: Desain, Kurikulum, Pendidikan Agama Kristen (PAK), Ibadah, Etos Kerja Kristen.

\section{A. Pendahuluan}

Kurikulum memiliki kedudukan dan peranan yang sangat penting dalam dunia pendidikan khususnya pendidikan formal, karena kurikulum berhubungan

dengan penentuan arah, isi dan proses pendidikan, yang pada akhirnya akan menentukan macam dan kualifikasi lulusan suatu institusi pendidikan. Kurikulum menyangkut rencana dan pelaksanakan pendidikan baik dalam
\end{abstract}


lingkup yang sempit seperti di kelas, sekolah, daerah, wilayah maupun nasional. Semua orang berkepentingan terhadap kurikulum, orangtua, masyarakat, pemimpin formal maupun informal selalu mengharapkan tumbuh dan berkembangnya anak-anak mereka, generasi yang lebih maju, pintar dan cerdas serta memiliki kompetensi yang handal untuk diri dan kehidupannya. Dalam konteks ini kurikulum memiliki andil yang cukup besar dalam melahirkan harapan tersebut.

Wina Sanjaya mengatakan istilah kurikulum (curriculum) adalah istilah yang digunakan di dalam dunia olahraga di mana akar kata curir (pelari) dan curere (tempat berpacu). Pada waktu itu kurikulum diartikan sebagai jarak yang harus ditempuh oleh dan setiap pelari bertujuan untuk memperoleh sebuah penghargaan. ${ }^{1}$ Orang mengistilahkannya dengan tempat berpacu atau tempat berlari dari mulai start sampai finish. Akhirnya pengertian ini digunakan di dalam dunia pendidikan yang mengacu kepada mata pelajaran yang harus ditempuh atau diselesaikan oleh seorang peserta didik dari awal sampai pada akhirnya. ${ }^{2}$ Singkatnya bahwa kurikulum tidak dapat terlepaskan dari pembelajaran. Junihot M. Simajuntak menjelaskan bahwa, kurikulum tidak hanya berbicara daftar dari materi pembelajaran yang perlu ditempuh oleh perserta didik dan juga bagaimana isi materi yang disajikan oleh pengajar kepada peserta didik. Oleh karena itu, bagi Junihot kurikulum tidak hanya berbicara soal dokumen tertulis yang harus

\footnotetext{
${ }^{1}$ Wina Sanjana, Kurikulum dan Pembelajaran (Jakarta: Kencana Prenada Media Group, 2009), 3. ${ }^{2}$ Ibid.

${ }^{3}$ Junihot M. Simajuntak, Implikasi Konsep dan Desain Kurikulum dalam Tugas Pembinaan Warga Jemaat (Jurnal Jafray, Vol.12), 252.
}

dipahami oleh peserta didik melainkan pengalaman belajar yang berlangsung. ${ }^{3}$

Dalam hal ini, maka kurikulum memberikan peranan yang penting baik dari bahan, penyampaian materi maupun pengalaman belajar sehingga kurikulum terencana dengan baik sebagai langkah yang akan ditempuh oleh peserta didik. Dengan demikian, maka tugas kurikulum adalah untuk merancang sebuah desain sebagai langkah atau usaha yang komunikatif yang melibatkan rekan secara beragam tetapi tetap berfokus kepada nara didik atau grup belajar. Dengan kata lain, kurikulum adalah merancang sebuah desain yang komunikatif dimana nara didik atau kelompok belajar dapat terlibat secara beragam.

Kurikulum pendidikan agama Kristen. Menurut Warner C. Graedorf Pendidikan Agama Kristen adalah "Proses pengajaran dan pembelajaran yang berdasarkan Alkitab, berpusat pada Kristus, dan bergantung kepada Roh Kudus, yang membimbing setiap pribadi pada semua tingkat pertumbuhan melalui pengajaran masa kini ke arah pengenalan dan pengalaman rencana dan kehendak Allah melalui Kristus dalam setiap aspek kehidupan, dan melengkapi mereka bagi pelayanan yang efektif, yang berpusat pada Kristus sang Guru Agung dan perintah yang mendewasakan pada murid, ${ }^{4}$ sedangkan E.G. Homrighausen mengatakan: "Pendidikan Agama Kristen berpangkal pada persekutuan umat Tuhan." 5 Selanjutnya Daniel Nuhamara menyebutkan PAK juga bertujuan untuk melengkapi mereka dalam pertumbuhan

\footnotetext{
${ }^{4}$ Paulus Lilik Kristianti, Prinsip dan Praktik Pendidikan Agama Kristen (Yogyakarta: Andi, 2006), 4.

${ }^{5}$ I.H. Enklaar dan E.G. Homrighousen, Pendidikan Agama Kristen (Jakarta: BPK Gunung Mulia, 2009), 112.
} 
iman melalui pelayanan yang efektif. ${ }^{6}$

Dengan demikian, maka pendidikan agama Kristen adalah sebuah pengajaran yang di dalamnya terdapat persekutuan yang intim kepada Tuhan yang membawa umat kepada pengenalan akan Allah dan karya-Nya yang membawa kepada kedewasaan hidup. Seperti yang dikemukakan oleh Rasul Paulus dalam Efesus 4:13 "Sampai kita semua telah mencapai kesatuan iman dan pengetahuan yang benar tentang anak Allah, kedewasaan penuh, dan tingkat pertumbuhan yang sesuai dengan kepenuhan Kristus." Kurikulum PAK adalah sebagai instrumen yang bertujuan melengkapi naradidik untuk menjalani imannya sebagai bagian dari kehidupan sehari-hari. sampai kita semua telah mencapai kesatuan iman dan pengetahuan yang benar tentang anak Allah, kedewasaan penuh, dan tingkat pertumbuhan yang sesuai dengan kepenuhan Kristus. Dalam hal ini kurikulum PAK sangat dibutuhkan dalam ibadah, pendalaman Alkitab, pembuatan tema-tema dalam setiap ibadah, dan kegiatan-kegiatan rohani lainnya yang bertujuan untuk menjawab kebutuhan iman spritualnya. Ibadah yang berlangsung di pemerintah Propinsi DKI Jakarta di Balai Kota tidak tersedia kurikulum PAK untuk ibadah tersebut.

Dalam hal ini, ibadah yang dilakukan oleh pegawai pemerintah di Balai Kota Provinsi DKI Jakarta. Ibadah tersebut berlangsung setiap hari Jumat pukul 12.00-13.30 WIB. Ibadah tersebut bertempat di Jalan Merdeka Selatan, Blok G Lantai 23, Balai Kota Jakarta. Ibadah Kristen ini dipersiapkan oleh seksi ibadah.

\footnotetext{
${ }^{6}$ Daniel Nuhamara, Pembimbing PAK (Bandung: Jurnal Info Media, 2007), 30.

7 Data Statistik Badan Kepegawaian Daerah Pegawai Krsiten Pemerintah di Balai Kota Provinsi DKI Jakarta, Rabu 25 Maret 2019.
}

Petugas pelayanan yang ambil bagian di dalamnya ditentukan oleh seksi ibadah tersebut. Menurut pengamatan penulis, jumlah kehadiran setiap minggunya tidak melebihi 50, padahal berdasarkan daftar pegawai Kristen yang ada di Badan Kepegawaian Daerah Provinsi DKI Jakarta lebih dari 213 orang Pegawai yang beragama Kristen. ${ }^{7}$

Para Pegawai Pemerintah di Balai Kota Propinsi DKI Jakarta mengatakan bahwa ibadah yang dilakukan setiap hari Jumat di bawah naungan Korps Pegawai Republik Indonesia (KORPRI) seringkali membosankan, ibadah dianggap tidak hidup serta situasi ibadah terasa monoton dan para pegawai yang bertugas juga kurang sigap dalam melayani bahkan terkesan kurang persiapan. Khotbah yang disampaikan kurang persiapan dan juga membuat pegawai sering terlihat mengantuk. Hal ini memperlihatkan bahwa banyak pegawai pemerintah Provinsi DKI Jakarta di Balai Kota tidak memahami pentingnya sebuah ibadah. Bahkan ketika mengundang Pendeta, para tim ibadah tidak menyampaikan apa yang menjadi tema dan sasaran yang hendak dicapai dalam setiap ibadah. Akibatnya ibadah terasa hambar dan hanya menjadi sebuah rutinitas yang menjenuhkan bagi yang menghadiri kebaktian tersebut. Tidak heran bila kemudian ada pegawai yang lebih memilih menghadiri kegiatan yang dianggap lebih memberikan semangat.

Berdasarkan percakapan tidak resmi dengan beberapa pegawai, penulis menemukan bahwa salah satu penyebab terjadinya ibadah yang tidak relevan ialah dikarenakan tidak adanya sebuah kurikulum. ${ }^{8}$ Dalam hal ini Wycoff

${ }^{8}$ Wawancara dengan Pengurus Ibadah dan Pegawai Kristen Pemerintah di Balai Kota Provinsi DKI Jakarta. 
memandang bahwa kurikulum dalam mengaktualkan tujuan pendidikan Kristen yang ada di Gereja tidak berdiri sendiri, melainkan melibatkan berbagai aspek yaitu: ${ }^{9}$ Pertama, dibutuhkan kejelasan susunan sasaran pencapaian di jemaat itu sendiri, untuk apa atau mengapa. Kedua, dibutuhkan Gereja yang benar-benar berdasar kepada Yesus Kristus. Ketiga, membutuhkan rumah tangga yang dibangun secara Kristen. Keempat, dibutuhkan sekolah Kristen yang dibangun oleh Gereja atau dasar firman Tuhan. Kelima, dibutuhkan bahan pengajaran yang benar sesuai firman Tuhan. Keenam, dibutuhkan komunitas yang menjadi konteks dan pelaksana pendidikan. Ketujuh, dibutuhkan wadah dan perlengkapan belajar. Kedelapan, dibutuhkan administrasi yang berdedikasi untuk melaksanakan tugas pembelajaran dan pendidikan.

Dalam hal ini yang menjadi peserta didik adalah pegawai Kristen pemerintah di Balai Kota Provinsi DKI Jakarta. Dalam hal ini sangat baik jika di ibadah yang dilakukan dalam pemerintah di Balai Kota Provinsi DKI Jakarta memiliki sebuah desain kurikulum pendidikan agama Kristen untuk ibadah. Karena dengan tidak adanya kurikulum di dalam ibadah Kristen akhirnya membuat pegawai pemerintah Provinsi DKI Jakarta di Balai Kota kurang terpanggil untuk masuk ke dalam ibadah tersebut.

Kata Ibadah berasal dari bahasa Ibrani yaitu yֵַבְדָ yang berarti mengusahakan tanah dalam Kejadian 3 : 23 dijelaskan bahwa manusia itu harus

\footnotetext{
${ }^{9}$ T D. Campbell Wyckoff, Theory and Design of Christian Education Curiculum (Philadelphia, PA: The Westminster Press, 1961), 25-27. Terkait dengan tugas pembinaan warga jemaat di Gereja, supaya pengajaran terarah dan optimal, maka Gereja membutuhkan kurikulum.
}

bekerja. Dalam hal ini kata ‘ăbôdâh tersebut sama dengan makna kata yang lebih dikenal dengan bahasa Arab yaitu "ibadah". Dalam hal ini kita memahami bekerja adalah ibadah. Istilah lain yang dipakai dalam ibadah adalah liturgi. Liturgi berasal dari bahasa Yunani

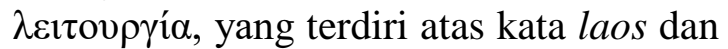
ergon. Laos berarti umat atau rakyat, sementara ergon berarti bekerja. Dalam Yunani kuno, liturgi adalah pekerjaan yang dilakukan oleh rakyat, sesuatu yang dilakukan untuk kepentingan kota atau Negara. ${ }^{10}$ Menurut Brownlee, ibadah bagi orang Kristen tidak hanya dilakukan melalui doa saja tetapi juga dilakukan dengan kehidupan. Artinya, ibadah tidak hanya terbatas pada upacara-upacara atau ritual tertentu tetapi diperlukan persembahan diri yang utuh kepada Tuhan. Brownlee berpendapat bahwa ibadah tidak hanya berkaitan dengan penyembahan atau persekutuan surgawi dengan Tuhan yang terpisah dengan masalah-masalah duniawi. Ibadah menolong manusia untuk menghadapi masalah yang ada di luar gedung Gereja dengan membawa masalah tersebut kepada Tuhan yang akan melengkapi manusia untuk menghadapi masalah dalam kehidupan sehari-hari. ${ }^{11}$

Dari pengertian di atas nampak jelas bahwa ibadah Kristen bukan hanya sebatas bernyanyi berdoa dan lainnya yang seperti biasa dilakukan oleh kebanyakan orang Kristen. Ibadah Kristen saat di mana Allah Yang Pengasih itu sendiri berbicara kepada kita melalui firman-Nya yang kudus dan bahwa kita pada gilirannya berbicara kepada-Nya dalam doa dan

\footnotetext{
${ }^{10}$ Eka Darmaputra, Etika Sederhana untuk Semua: Bisnis, Ekonomi dan Penatalayanan (Jakarta: BPK Gunung Mulia, 2001), 101.

11 Malcolm Brownlee. Tugas Manusia dalam Dunia Milik Tuhan: Dasar Theologis Bagi Pekerjaan Orang Kristen dalam Masyarakat (Jakarta: BPK Gunung Mulia, 2004), 19.
} 
nyanyian pujian. Terciptanya ibadah karena Allah sendiri yang berinisiatif memanggil manusia untuk datang kepadaNya dan bertobat. Ibadah adalah tindakan Allah untuk menyatakan kasih-Nya dan manusia dipanggil untuk menjawab perbuatan kasih-Nya dan melayani-Nya melalui kehidupan sehari-hari. Oleh karena itu, ibadah Kristen yang dilakukan di kawasan Balai Kota sangat penting dihidupkan dan kembali kepada hakikat ibadah itu sendiri, khususnya dalam kehidupan pegawai pemerintah Provinsi DKI Jakarta di Balai Kota dalam membangun sebuah etos kerja. Banyak dari pegawai pemerintah Provinsi DKI Jakarta di Balai Kota beranggapan bahwa ibadah tersebut tidak memiliki pengaruh yang signifikan terhadap etos kerja.

Dalam hal ini, etos kerja berarti memiliki kunci sebagai semangat kerja yang menjadi ciri khas dan keyakinan. Jika kembali berangkat dari kata "Etos Kerja" pada dasarnya terdiri dari kata "etos" dan "kerja". Namun, ada juga beberapa penulis buku menyebutkan dalam ejaan yang berbeda yakni "Ethos Kerja" namun bagi K. Bartens kata "ethos" sejatinya tetap tertulis sesuai dengan ejaan aslinya. Di dalam Kamus Besar Bahasa Indonesia (KBBI), etos diartikan sebagai pandangan hidup yang khas dari suatu golongan sosial. Berarti etos berbicara soal pandangan hidup yang di dalamnya memiliki kekhasan di dalam sebuah kelompok sosial, hal ini diperkuat dengan penjelasan Eka Darmaputera yang mengatakan bahwa etos itu adalah semacam nilai yang membudaya dalam sebuah masyarakat. Berarti pandangan hidup yang khas ini memiliki nilai yang hidup di tengah-tengah masyarakat.

12 Eka Darmaputra, Op.Cit., 112-113.

13 Jansen H. Sinamo, Etos Kerja Profesional Navigator Anda Menuju Sukses (Jakarta: Spirit Mahardika, 2011), 55.
Sedangakan kata kerja sendiri pun artinya sebagai kegiatan melakukan sesuatu; yang dilakukan. Jika menggali kata kerja di dalam Alkitab sendiri tentunya memiliki berbagai pemahaman yang berisikan nilainilai yang tidak ada habisnya. Hal ini terlihat bagaimana Alkitab memperkenalkan gambaran Allah yang terus bekerja. Gambaran ini bagi Eka Darmaputera merupakan salah satu dari hakikat-Nya sebagai Allah dan saat Allah bekerja, bagi Ia karena Bekerja itu baik. Hal ini pun berlaku bagi manusia dimana di dalam teks Kejadian 2:15 berbicara bagaimana Allah menempatkan manusia untuk mengusahakan dan memelihara taman itu, berarti manusia pada dasarnya memiliki ciri untuk bekerja. ${ }^{12}$

Dengan demikian, maka etos kerja bisa diartikan sebagai suasana khas (budaya) bekerja dalam suatu kelompok yang dilandasi pada suatu sistem nilai yang fungsional. Le Jansen Sinamo menjelaskan bahwa etos kerja merupakan seperangkat perilaku kerja positif yang berakar pada kerjasama yang kental, keyakinan yang fundamental, disertai komitmen yang total pada paradigma kerja yang integral. ${ }^{13}$ Oleh sebab itu, etos kerja memerlukan kerjasama, keyakinan dan komitmen yang harus dimiliki oleh setiap pekerja. Tidak hanya dimiliki, melainkan menjadi sebuah kepribadian yang mampu mengekspresikan, memandang, meyakini dan juga dapat memberikan makna pada sesuatu. Selain itu, etos kerja mencerminkan suatu sikap yang memiliki dua alternatif, positif dan negatif. Suatu individu atau kelompok masyarakat dapat dikatakan memiliki etos kerja yang tinggi apabila menunjukkan tanda-tanda sebagai berikut: ${ }^{14}$ (1) Mempunyai penghargaan

\footnotetext{
${ }^{14}$ Kusnan, Ahmad (2004); Analisis Sikap Iklim Organisasi, Etos Kerja dan Disiplin Kerja Dalam Menentukan Efektifitas Kinerja Organisasi di Garnizun Tetap III Surabaya.
} 
yang sangat positif terhadap hasil kerja manusia, (2) Menempatkan pandangan tentang kerja, sebagai suatu hal yang amat luhur bagi eksistensi manusia, (3) Kerja yang dirasakan sebagai aktivitas yang bermakna bagi kehidupan manusia, (4) Kerja dihayati sebagai suatu proses yang membutuhkan ketekunan dan sekaligus sarana yang penting dalam mewujudkan cita-cita, (5) Kerja dilakukan sebagai bentuk ibadah.

Dalam hal ini, para pegawai Kristen yang bekerja di Balai kota memiliki pandangan yang sempit mengenai etos kerja Kristen. Hal ini terlihat dalam keseharian dalam bekerja. Kerja dirasakan sebagai suatu hal yang membebani diri, kurang dan bahkan tidak menghargai hasil kerja manusia, kerja dipandang sebagai suatu penghambat dalam memperoleh kesenangan, kerja dilakukan sebagai bentuk keterpaksaan, kerja dihayati hanya sebagai bentuk rutinitas hidup. Kesadaran akan etos kerja harus dimiliki setiap orang khususnya para pekerja Kristen. Menurut Eka Darmaputera etos kerja merupakan sebuah panggilan pada manusia untuk mewujudkannya, dengan mampu mewujudkan etos kerja berarti kita semakin memberikan penghargaan terhadap waktu, materi dan kerja itu sendiri. Salah satu semboyan yang juga menggambarkan mengenai etos kerja Kristen adalah "berdoa dan bekerja" (ora et labora). Semboyan ini pada kenyataannya masih dipisahkan baik berdoa maupun bekerja. Pemikiran Luther yang dijelaskan oleh Eka Darmaputera menjelaskan bahwa doa tidak dengan sendirinya bermakna daripada "kerja", sebab "kerja" juga dapat dilihat sebagai "doa". ${ }^{15}$ Dengan demikian, maka makna ora et labora sejatinya berdoa adalah bekerja, sebab berdoa yang benar adalah bekerja dengan penuh tanggung jawab serta disiplin sedangkan bekerja dengan penuh tanggung jawab dan disiplin merupakan doa dan ibadah kepada Tuhan.

Sesuai dengan pembahasan etos kerja tersebut di atas, maka Sama halnya dengan ibadah. Ibadah mengarahkan kita kepada sebuah respon terhadap panggilan Allah. Untuk itulah kurikulum perlu didesain dengan baik, khususnya untuk ibadah Kristen agar pada nantinya mereka pun mendapati panggilannya untuk dapat mewujudkan sebuah etos kerja Kristen. Bagi para pegawai pemerintah Provinsi DKI Jakarta di Balai Kota mereka mempunyai pendapat bahwa bekerja itu punya nilai sendiri dan ibadah itupun sendiri. Artinya mereka memisahkan keduanya. Hal ini terlihat dari ibadah tersebut jarang mengarah kepada etos kerja.

Untuk itu peneliti bermaksud membuat sebuah desain kurikulum PAK dalam ibadah yang berorientasi kepada etos kerja Kristen. Dari latar belakang masalah yang sudah dipaparkan di atas, maka penulis tertarik untuk melakukan penelitian.

\section{B. Tinjauan Teoritis}

1. Desain Kurikulum Pendidikan Agama Kristen

\section{a. Pengertian Desain Kurikulum}

Desain berasal dari bahasa Inggris "design" yang berarti rancangan, rencana atau reka rupa dari kata design muncullah kata desain yang berarti mencipta, memikir atau merancang. Desain dapat diartikan sebagai rancangan yang merupakan susunan dari garis, bentuk, ukuran, warna serta value dan benda yang

${ }^{15}$ Eka Darmaputra, Op.Cit., 111. 
dibuat berdasarkan prinsip-prinsip desain "kata benda". Desain dapat diartikan sebagai proses perencanaan bentuk dengan tujuan supaya benda yang dirancang, mempunyai fungsi atau berguna serta mempunyai nilai keindahan. ${ }^{16}$ Nana Sudjana mengatakan kurikulum merupakan niat dan harapan yang dituangkan ke dalam bentuk rencana maupun program pendidikan yang dilaksanakan oleh para pendidik di sekolah. Kurikulum sebagai niat dan rencana, sedangkan pelaksaannya adalah proses belajar mengajar yang terlibat didalam proses tersebut yaitu pendidik dan peserta didik. ${ }^{17}$ Kurikulum menurut UU No. 20 Tahun 2003, adalah seperangkat rencana dan pengaturan mengenai tujuan, isi, dan bahan pelajaran serta cara yang digunakan sebagai pedoman penyelenggaraan kegiatan pembelajaran untuk mencapai tujuan pendidikan nasional. ${ }^{18}$

Desain kurikulum dapat diartikan sebagai kerangka, pola, bagaimana kurikulum dirancang dan dikembangkan atau diorganisasikan. Menurut Nasution dinyatakan bahwa dalam organisasi atau desain kurikulum, dicoba diwujudkan apa yang diketahui tentang teori, konsep, pandangan tentang pendidikan, perkembangan anak dan kebutuhan masyarakat. 19 Nana Sukmadinata mengatakan desain kurikulum ialah menyangkut pola pengorganisasian unsurunsur atau komponen kurikulum. Penyusunan desain kurikulum dapat dilihat dari dua dimensi, yaitu dimensi horizontal dan dimensi vertikal. Dimensi

\footnotetext{
${ }^{16}$ Wina Sanjaya, Perencanaan dan Desain Sistem Pembelajaran (Jakarta: Kencana. 2008), 65.

${ }^{17}$ Nana Sudjana, Pembinaan dan Pengembangan Kurikulum di Sekolah (Jakarta: Sinar Baru, 1989), 56-57.

${ }^{18}$ Undang-Undang Republik Indonesia Nomor 20 Tahun 2003 Tentang Sistem Pendidikan Nasional
}

horizontal berkenaan dengan penyusunan dari lingkup isi kurikulum, sedangkan dimensi vertikal menyangkut penyusunan bahan berdasarkan urutan tingkat kesukaran. ${ }^{20}$

Dengan demikian, maka desain kurikulum adalah suatu usaha yang dilakukan dalam rangka merancang atau membuat pola tentang teori, konsep, pandangan tentang sebuah kebutuhan dari anak didik disampaikan dalam pengajaran.

\section{b. Desain Kurikulum Berorientasi Pada Disiplin IImu}

\section{1) Subject Centered Curriculum}

Kurikulum mata pelajaran atau subject curriculum terdiri dari mata pelajaran (subject) yang terpisah-pisah, dan subject itu merupakan himpunan pengalaman dan pengetahuan yang diorganisasikan secara logis dan matematis oleh para ahli kurikulum. Dalam hal ini, kurikulum ini cenderung menjadi statis dan tidak bersifat inovatif, karenanya berdasarkan kepada buku yang telah ditetapkan, tanpa mengalami perubahan penyesuaian yan berarti situasi masyarakaag selalu berkembang dengan pesat dan dinamis.

\section{2) Correlated Curriculum}

Correlated curriculum adalah
sebuah bentuk kurikulum yang menunjukkan adanya suatu hubungan antara satu mata pelajaran dengan mata pelajaran lainnya, tetapi tetap memperhatikan ciri atau karakteristik tiap bidang studi tersebut. ${ }^{21}$ Kurikulum jenis

\footnotetext{
${ }^{19}$ Nana Sudjana, Opcit., 8.

${ }^{20}$ Nana Syaodih Sukmadinata, Pengembangan Kurikulum: Teori dan Praktek (Bandung: Rosda Karya, 1997), 28-29.

21 Syafruddin Nurdin, Guru Profesional dan Implementasi Kurikulum (Jakarta: Quantum Teaching, 2005), 45.
} 
ini mengandung makna bahwa sejumlah mata pelajaran dihubungkan antara yang satu dengan yang lain sehingga ruang lingkup bahan yang tercakup semakin luas. Artinya bahwa Correlated Curriculum adalah suatu bentuk pengorganisasian kurikulum yang menunjukkan adanya suatu hubungan antara satu mata pelajaran dengan mata pelajaran lainnya, akan tetapi tetap memperhatikan ciri/karakteristik tiap bidang studi, misalnya terdapat suatu pokok permasalahan yang diperbincangkan dalam berbagai bidang studi.

\section{3) Integrated curriculum}

Integrated curriculum merupakan konsep desain kurikulum yang menggunakan model integrated, yakni tidak lagi menampakkan nama mata pelajaran atau bidang studi. Belajar dari suatu pokok permasalahan yang harus diselesaikan, masalah tersebut kemudian dinamakan unit. Belajar berdasarkan unit bukan hanya menghafal sejumlah fakta, tetapi juga mencari dan menganalisis fakta-fakta sebagai bahan materi dalam memecahkan masalah. ${ }^{22}$ Belajar melalui pemecahan masalah itu diharapkan perkembangan siswa tidak hanya terjadi pada segi intelektual saja, tetapi seluruh aspek seperti sikap, emosi, dan keterampilan.

\section{c. Desain Kurikulum Berorientasi pada Masyarakat}

\section{1) Perspektif Status Quo (Status Quo Perspective)}

Kurikulum ini disusun dan diarahkan untuk melestarikan nilai-nilai budaya masyarakat, dalam hal ini

22 Syafruddin Nurdin, Guru Profesional dan Implementasi Kurikulum (Jakarta: Quantum Teaching, 2005), 41. merencanakan untuk memberikan pengetahuan dan keterampilan kepada peserta didik sebagai persiapan menjadi orang dewasa yang dibutuhkan dalam kehidupan masyarakat. Franklin Bobbit mengkaji secara ilmiah berbagai kebutuhan masyarakat yang harus menjadi isi kurikulum. Sekolah sebagai suatu lembaga pendidikan formal harus mendidik anak agar menjadi manusia dewasa dalam masyarakatnya. Kemudian menetapkan kegiatan-kegiatan utama dalam kehidupan masyarakat yang disarankan untuk menjadi isi kurikulum, diantaranya: (a) Kegiatan yang akif dalam nuansa komunikasi sosial, (b) Kegiatan yang bersenuhan dengan kesehatan. (c) Kegiatan dalam kehidupan sosial seperti bergaul dan berkelompok dengan orang lain. (d) Kegiatan menggunakan waktu senggang dan menikmati rekreasi. (e) Usaha menjaga kesegaran jasmani dan rohani. (f) Kegiatan yang berhubungan dengan religius. (g) Kegiatan yang berhubungan dengan peran orangtua seperti membesarkan anak, memelihara kehidupan keluarga yang harmonis. (h) Kegiatan praktis yang bersifat vokasi atau keterampilan tertentu. (i) Melakukan pekerjaan sesuai dengan bakat seseorang.

\section{2) Perspektif Pembaharuan (The Reformist Perspective)}

Kurikulum dalam perspektif ini dikembangkan untuk lebih meningkatkan kualitas masyarakat pada daerah tersebut, disebabkan karena hal tersebut merupakan menghendaki peran serta masyarakat total dalam proses pendidikan. Paulo Friere dan Ivan Illich, tokoh dalam perspektif ini berpendapat bahwa kurikulum yang sekedar mencari pemecahan masalah 
sosial tidak akan memadai. ${ }^{23}$ Dengan demikian, kurikulum sebagai rancangan pendidikan seharusnya mampu merombak tata sosial dan lembaga-lembaga sosial yang sudah ada dan membangun struktur sosial baru.

\section{3) Perspektif Masa Depan (The Futurist Perspective)}

Perspektif ini sering dikaitkan dengan kurikulum rekontruksi sosial, yang menekankan pada proses mengembangkan hubungan antara kurikulum dan kehidupan sosial, politik, dan ekonomi masyarakat. Model kurikulum ini lebih mengutamakan kepentingan sosial dibandingkan kepentingan individu. Setiap individu harus mampu mengenali berbagai permasalahanyang ada di masyarakat yang senantiasa mengalami perubahan yang sangat cepat. Tujuan utama dalam perspektif ini adalah mempertemukan peserta didik dengan masalah-masalah yang dihadapi umat manusia namun masalah yang dihadapi masyarakat bukan hanya dapat dipecahkan melalui "bidang studi sosial" saja tetapi juga oleh setiap disiplin ilmu termasuk ekonomi, estetika, kimia, dan matematika.

\section{d. Desain Kurikulum Berorientasi pada Siswa}

1) Desain Terpusat

Kegiatan/Pembelajaran

Pada desain ini, siswa memiliki motivasi dalam diri dalam melakukan kegiatan belajar, karena setiap kegiatan yang disusun sesuai dengan kebutuhan, minat dan keinginan siswa. Menurut Zais yang dikutip oleh Muhamad para siswa

23 Paulo Friere dan Ivan Illich, Menggugat Pendidikan-Fundamentalis, Konservatif, Liberal, Anarkis (Pustaka Pelajar: 2015), 58-59. tidak memerlukan motivasi eksternal sebab fakta, konsep, keterampilan dan proses yang mereka pelajari bermanfaat bagi mereka, bukan karena konten itu dibutuhkan bagi studi lanjututan atau karena akan dites oleh guru, kegiatan belajar disesuaikan dengan keinginan siswa. $^{24}$

\section{2) Desain Sekolah Alternatif}

Para reformer radikal menegaskan tidak ada kurikulum sebelum siswa berada di sekolah dan sampai kebutuhan dan minat mereka diketahui. John Holt menegaskan sangat aneh jika kurikulum diartikan sebagai kumpulan pengetahuan yang harus dipelajari siswa dan tidak percaya konten itu yang bermanfaat bagi kehidupan siswa. Artinya anak-anak memiliki kemampuan dasar untuk menentukan pengalaman apa yang terbaik bagi pembelajaran mereka sendiri.

\section{3) Desain Humanistik}

Dalam hal ini, desain humanistik menyediakan lingkungan belajar yamg kondusif bagi siswa agar mereka berkembang menjadi manusia yang seutuhnya. Pembelajaran yang bermakna harus self-intiated, inisiatif siswa sendiri. Walaupun dorongan belajar berasal dari luar siswa, keinginan melakukan penemuan dan motivasi untuk belajar, perlu dikembangkan agar datang dari dalam diri sendiri yang dimungkinkan oleh keutuhan manusia itu sendiri dalam merealisasikan kemampuan, kesejahteraan, dan pengembangan diri. ${ }^{25}$

\footnotetext{
${ }^{24}$ Mohamad Ansyar, Kurikulum, Hakikat, Fondasi, Desain dan Pengembangan (Jakarta: Kencana, 2015), 277.

${ }^{25}$ Ibid., 281
} 


\section{4) Pendidikan Agama Kristen}

Pendidikan Agama Kristen (PAK) merupakan pendidikan yang sangat penting, sebab PAK membawa setiap orang mengenal, memahami dan mengalami kasih dan karya Allah serta rencana-Nya dalam panggilan hidup sebagai orang Kristen yang dapat diperoleh baik dalam keluarga, gereja, sekolah dan masyarakat. PAK adalah Pendidikan Agama Kristen adalah pendidikan yang bercorak, berdasar, dan berorientasi Kristiani serta dapat memerdekan setiap orang yang percaya kepada Tuhan Yesus dari perbudakan dosa serta membawa orang dalam persekutuan Kristen supaya menerima pengampunan dan kekuatan dengan ucapan syukur dan ketaatan sertadimampukan untuk bertumbuh menjadi orang yang setia melaksanakan panggilan-Nya. ${ }^{26}$

Harianto GP menjelaskan bahwa Pendidikan Agama Kristen adalah proses pengajaran dan pembelajaran yang berdasarkan Alkitab, berpusat pada Kristus dan bergantung pada kuasa Roh Kudus, yang membimbing setiap pribadi pada semua tingkatan pertumbuhan, melalui pengajaran masa kini kearah pengenalan dan pengalaman rencana dan kehendak Allah melalui Kristus dalam segala aspek kehidupan, dan memperlengkapi mereka bagi pelayanan yang efektif, dan berpusat kepada Kristus Sang Guru Agung dan perintah yang mendewasakan para murid. ${ }^{27}$

\footnotetext{
${ }^{26}$ Samuel Sidjabat, Startegi Pendidikan Kristen: Suatu Tinjuan Teologis-Filosofis (Yogyakarta: Andi,1996), 27.

${ }^{27}$ Harianto GP, Pendidikan Agama Kristen dalam Alkitab \& dunia Pendidikan Masa Kini (Yogyakarta: Andi, 2012), 16.

28 Robert E. Clark, Lin Johnson, Christian Education Foundations For The Future (Chicago: Moody Publishers, 1991), 11.
}

Desain Pendidikan Agama Kristen harus berpusat pada Yesus Kristus yang diberitakan di dalam Alkitab. Dalam kurikulum PAK diberikan tempat di mana peserta didik dapat ditolong untuk memahami pekerjaan Roh Kudus melalui kehidupan gereja. ${ }^{28}$ Desain Kurikulum PAK ialah merupakan suatu pengorganisasian tujuan, isi, serta proses belajar yang akan diikuti pada berbagai tahap perkembangan pendidikan yang berpusat kepada Alkitab. Eli Tanya menjelaskan bahwa kurikulum berarti lapangan perlombaan yang harus dilalui oleh murid danguru untuk mencapai tujuan tertentu. ${ }^{29}$ Dalam hal ini, rumusan tetang kurikulum PAK dari International Concil of Religius Education, yaitu kurikulum PAK adalah pengalaman si pelajar di bawah bimbingan. Semua pengalaman murid dalam rumah tangga, Gereja, masyarakat dan sekolah digunakan untuk mencapai tujuan pendidikan Gereja. Kurikulum yang berorientasi pada Alkitab sebagai kegiatan-kegiatan yang berkaitan dengan isi berotoritas yang dibimbing atau dilaksanakan oleh pemimpin Kristen agar dapat membawa para siswa satu langkah lebih dekat kepada kedewasaan di dalam Kristus. Kegiatan-kegiatan ini melibatkan interaksi dari pengajar dan para siswa dengan Firman Allah. ${ }^{30}$

Kurikulum adalah konten yang disediakan bagi peserta didik dalam pengalaman pembelajaran mereka yang aktual yang dipandu oleh seseorang pengajar. Implementasinya ialah pengajar harus tanggap dengan tanggung jawabnya

29 Eli Tanya, Gereja dan Pendidikan Agama Kristen (Jawa Barat Sekolah Tinggi Teologi Cipanas: 1999), 16-17.

${ }^{30}$ Lois E. Lebar, Education That Is Christian Proses Belajar Mengajar Kristiani \& Kurikulum Yang Alkitabiah (Jawa Timur: Gandum Mas, 2006), 307. 
dalam menyampaikan konten, dan pemgalaman saat merencanakan, mengimplementasikannya, dan mengevaluasi pengajarannya. Tantangan bagi penyusunan kurikulum adalah menggabungkan konten Kristen dan pengalaman sehingga pikiran dan kehidupan peserta didik akan dipengaruhi dan diubahkan oleh kebenaran Allah. ${ }^{31}$

Dalam hal ini, kurikulum PAK adalah sejumlah bahan pelajaran agama Kristen yang dirumuskan berdasarkan isi Alkitab dengan berbagai pendekatan seperti pendekatan dogmatis, eksegetis, etika serta pengalaman belajar agama Kristen yang direncanakan untuk membawa perubahan perilaku peserta didik dalam komunitas Kristen. Dalam hal ini, kurikulum PAK juga merupakan desain kelompok sosial komunitas Kristen dari berbagai denominasi Gereja yang secara sepakat membuat pokok-pokok kajian pelajaran agama untuk menjadi pengalaman belajar anak-anak Kristen di sekolah.

\section{Ibadah}

Ibadah merupakan suatu kegiatan utama dalam sebuah agama yang dapat kita temui disemua agama. Walaupun demikian, pemahaman tentang ibadah serta bentuk dan tatanan ibadah masingmasing agama berbeda antara agama yang satu dengan yang lainnya. Perbedaan ini disebabkan karena perbedaan isi kepercayaan masing-masing agama tersebut. Ibadah dalam Bahasa Ibrani "avoda" dan Yunani "latreia" yang berarti "mengabdi" atau "pelayanan". Pada mulanya kata tersebut digunakan menyatakan pekerjaan budak atau hamba

31 Robert W, Pazmino, Fondasi Pendidikan Kristen: Sebuah Pengantar dalam Perspektif Injil (Bandung: STT Bandung dan BPK Gunung Mulia, 2012), 323.

32 Eka Darmaputra, Op.Cit., 129. upahan. Dan dalam rangka mempersembahkan ibadat ini kepada Allah, maka para hamba-Nya harus meniarap. Ibrani "hisyatakhawa" atau Yunani "proskuneo" mengungkapkan rasa takut penuh hormat, kekaguman dan ketakjuban penuh pujian. ${ }^{32}$

Menurut Kamus Besar Bahasa Indonesia, "ibadah" adalah perbuatan yang menyatakan bakti kepada Allah yang di dasari ketaatan melakukan perintah-Nya dan menjauhi larangan-Nya. Sedangkan ibadat diartikan segala usaha lahir batin sesuai dengan perintah Tuhan untuk mendapatkan kebahagian dan keseimbangan hidup, baik untuk diri sendiri, keluarga dan masyarakat maupun terhadap alam semesta. Kata ibadah dalam bahasa Inggris "worship" yang diambil dari bahasa Saxon, weorthscipe,yang artinya menyatakan layak atau penghargaan pada seseorang yang dinilai layak atau diberi penghormatan. Oleh karena itu, di dalam ibadah Kristen yang menjadi tujuan ibadah adalah hanya Yesus. ${ }^{33}$ Ibadah Kristen ialah di mana jemaat sebagai umat Allah berkumpul untuk berbakti kepada Allah dan untuk mendengarkan firman-Nya.

Ibadah Kristen adalah Penyataan diri Allah sendiri dalam Yesus Kristus dan tanggapan manusia terhadap-Nya serta Allah sedang bertindak untuk memberikan hidup-Nya bagi manusia dan membawa manusia mengambil bagian dalam kehidupan, karenanya semua yang kita lakukan sebagai individu-individu atau Gereja dipengaruhi oleh ibadah. ${ }^{34}$ Ibadah Kristen juga sebagai pelayanan Allah kepada Jemaat dan Pelayanan Jemaat terhadap Allah serta ibadah Kristen juga

${ }^{33}$ J. L. Ch. Abineno, Gereja dan Ibadah (Jakarta: BPK Gunung Mulia, 1986).

${ }^{34}$ James F. White, Pengantar Ibadah Kristen (Jakarta: BPK Gunung Mulia, 2012), 12. 
merupakan pemberian Allah mengundang penyembahan manusia kepada Allah. ${ }^{35}$

\section{a. Tujuan Ibadah}

Tujuan utama ibadah ialah untuk bersekutu dengan Tuhan dan memuliakanNya sehingga pemujaan dan persekutuan menjadi tujuan yang terpenting dalam kehidupan manusia bukan sebagai alat untuk mencapai sesuatu hal. Dasar dari ibadah menurut Brownlee adalah penyerahan diri kepada Tuhan agar manusia dapat dijadikan alat untuk pekerjaan Tuhan di dunia. Manusia dituntut hidup untuk Allah dan sesama. Singkatnya, makna ibadah menurut Brownlee ialah persekutuan dan pertemuan manusia dengan Allah melalui penyerahan diri manusia kepada Allah untuk menjadi saksi Allah dalam dunia sehingga manusia perlu beribadah dengan benar. ${ }^{36}$

\section{b. Unsur-unsur ibadah}

\section{1) Nyanyian (puji-pujian)}

Salah satu hal yang harus ada ketika melakukan Ibadah Kristen di Gereja Tuhan ialah nyanyian atau yang disebut dengan puji-pujian yang merupakan sikap penyembahan kepada Allah. Andrew Murray mengatakan bahwa penyembahan bersama di dalam gereja atau persekutua rohani lainnya sangat perlu untuk semua orang Kristen. Persekutuan bersama adalah jalan untuk membangun relasi dengan Tuhan dan sesama. Jika orang Kristen mundur dari kewajiban itu, maka membuka pintu kepada dosa dan

\footnotetext{
35 Ibid., 33.

${ }^{36}$ Malcolm Brownlee. Tugas Manusia dalam Dunia Milik Tuhan: Dasar Theologis bagi Pekerjaan Orang Kristen dalam Masyarakat (Jakarta: BPK Gunung Mulia, 2004), 19-20.

${ }^{37}$ J. Wesley Brill, Tafsiran Surat Ibrani (Bandung: Kalam Hidup 1973), 187.
}

kebinasaan. ${ }^{37}$ Alkitab menjelaskan bahwa penyembahan berbicara tentang menyambut Allah dengan cara yang benar. Dalam bahasa aslinya, bahasa Yunani disebut $\pi \rho 0 \sigma \kappa v v \varepsilon \omega$ atau Proskuneo yang artinya mendekati Dia dengan penuh kasih dan hormat untuk mencium Dia. ${ }^{38}$ Dalam hal ini, penyembahan yang dilakukan yang berarti mengingat segala kebaikan yang telah diberikan oleh Tuhan. Sehingga diakui sebagai berkat-berkat rohani dan jasmani yang selama ini telah diterima. Nyanyian tersebut biasanya dilakukan dalam bentuk koor atau vokal grup dan juga nyanyian solo. Tulisan Rasul Paulus tampaknya banyak di sisipi dengan nyanyian himne misalkan Filipi 2:5-11.

\section{2) Doa}

Doa merupakan salah satu unsur ibadah Kristen di dalam Gereja Tuhan. Rasul Paulus juga mengatakan bahwa di dalam doa memiliki tiga unsur utama yaitu permohonan atau doa pribadi, doa syafaat dan juga bermakna kerinduan kepada Tuhan. ${ }^{39}$ Doa adalah tindakan pertama yang menghubungkan pengajaran dengan praktik dan semua latihan yang lain dari kehidupan rohani atau spiritualitas seorang pelayan Tuhan. Banyak orang menemukan bahwa kehidupan rohani atau spiritualitas mereka bertumbuh melalui satu latihan rohani utama yaitu doa. Tujuan kehidupan Kristen adalah untuk menikmati persatuan dengan Allah-memuliakan Allah dan menikmati Allah untuk selamalamanya, untuk menggenapi tujuan akhir kita diciptakan. ${ }^{40}$

\footnotetext{
${ }^{38}$ Djohan E. Handojo, The Fire of Praise and Worship, Tujuh Langka Menjaga Api Pujian dan Penyembahan Tetap Menyala dengan Urapan Baru (Yogyakarta: Penerbit ANDI, 2007), 12.

${ }^{39}$ Abineno, Op.Cit., 43.

${ }^{40}$ Ibid., 44.
} 


\section{3) Firman Tuhan}

Firman Tuhan merupakan salah satu unsur ibadah yang terdiri dari bacaanbacaan ayat Alkitab sekaligus dengan penjelasannya. Hal ini biasa disebut sebagai khotbah atau pengajaran. Khotbah adalah pelayanan rohani, Hasan Sutanto membenarkan bahwa berkhotbah adalah pelayanan yang bersifat rohani. ${ }^{41}$ Firman Tuhan ialah mendengar dan Firman Allah, yang disampaikan dan diekspresikan melalui ucapan manusia. Beliau menyebutkanpula Allah berbicara kepada kita melalui pembacaan dan Khotbah, dibacakan dan dikhotbahkan oleh manusia. Apa yang dilakukan Allah di sini dilakukan terutama melalui Firman yang diucapkan. ${ }^{42}$

\section{4) Perjamuan Kudus}

Perjamuan Kudus sering disebut dengan Sakramen Ekaristi. Istilah Ekaristi berasal dari bahasa Yunani Eucharistia merupakan terjemahan Yunani untuk bahasa Yahudi birkat yang dalam perjamuan Yahudi merupakan doa puji syukur sekaligus permohonan atas karya penyelamatan Allah. ${ }^{43}$ Perjamuan Kudus adalah tidak hanya sebatas mengingat kembali makna dari kesengsaraan dan kematian Yesus dalam menebus manusia dari hukuman dosa, akan tetapi juga memberitakan kematian-Nya hingga Ia datang kembali. ${ }^{44}$

\section{5) Persembahan}

Salah satu unsur di dalam rangkaian peribadahan umat Kristen

\footnotetext{
${ }^{41}$ Hasan Sutanto, Homiletik, Prinsip dan Metode Berkhotbah (Jakarta: BPK Gunung Mulia, 2004), 173.

42 James F. White, Op.Cit., 155-156.

43 Martasudjita.Pr, Sakramen-Sakramen Gereja (Tinjauan Teologis, Liturgis, dan Pastoral) (Yogyakarta: Kanisius, 2003), 269.
}

adalah pemberian persembahan. Unsur pemberian persembahan mengambil bagian yang penting, dan digunakan sebagai wujud ungkapan rasa terima aksih atas anugerah Tuhan bagi kehidupan manusia. Pemberian persembahan juga merupakan manifestasi dari tindakan kehidupan sehari-hari. ${ }^{45}$ Dalam gal ini,setelah Jemaat diberkati maka akan dilakukan suatu respon berupa persembahan yang diberikan kepada Tuhan. Hal ini dimaksudkan untuk memberikan kasih sayang kepada Tuhan. Seperti halnya disinggung pada Alkitab baru Ibadah Kristen, bahwa Rasul Paulus menyinggung untuk melakukan persembahan kepada Gereja Korintus dalam setiap minggunya ketika beribadah.

\section{Etos Kerja}

\section{a. Pengertian Etos kerja}

Etos kerja adalah refleksi dari sikap hidup yang mendasar dalam menghadapi kerja. Sebagai sikap hidup yang mendasar, maka etos kerja pada dasarnya juga merupakan cerminan dari pandangan hidup yang berorientasi pada nilai yang berdimensi transenden. Nilainilai transenden itu akan menjadi dasar bagi pengembangan spritualitas, yang sangat diperlukan sebagai kekuatan yang membentuk suatu kepribadian, yang menentukan kualitas eksistensial dalam hidupnya. $^{46}$

\section{b. Pengertian Etos Kerja Kristen}

Etos Kerja Kristen menurut Jansen Sinamo adalah perilaku kerja positif yang

\footnotetext{
${ }^{44}$ Ebenhaizer Nuban Timo, Makanan adalah Surga (Jakarta: BPK Gunung Mulia, 2015), 371.

${ }^{45}$ Einar Situmpol, Gereja Menyikapi Perubahan (Jakarta: BPK Gunung Mulia, 2004), 159.

46 Asy'ari, Musa, Islam., Etos Kerja dan Pemberdayaan Umat (Yogyakarta: Lembaga Studi Filsafat Islam LESFI, 2007), 33-34.
} 
lahir sebagai buah dari keyakinan dan komitmen total pada paradigma kerja tertentu serta keyakinan yang mendalam serta komitmen yang kuat pada nilai-nilai kerja tertentu yang tampak keluar sebagai perilaku kerja yang positif serta bekerja merupakan suatu panggilan dalam kehidupan manusia sehingga ia harus bekerja efektif dan berkualitas serta menghasilkan nilai-nilai Kristiani dalam berkerja. $^{47}$

Faktor-Faktor yang Mempengaruhi Etos Kerja Secara umum, Etos kerja dipengaruhi oleh beberapa faktor yang diantaranya yaitu: ${ }^{48}$ agama, budaya, sosial politik, kondisi lingkungan, pendidikan, struktur ekonomi, motivasi instrinsik individu.

\section{c. Aspek-Aspek Etos Kerja Kristen}

\section{1) Bekerja Adalah Anugerah:}

Aku Bekerja Penuh Kebersyukuran Rahmat adalah kebaikan yang kita terima tanpa kualifikasi, tanpa syarat. Sinonimnya: anugerah, kasih karunia, yaitu kebaikan yang kita terima karena kasihsayang dari yang memberi. Anugerah ialah fasilitas ilah dan sangu sorgawi bagi pertumbuhan dan kemajuan manusia menuju kepenuhan insaniah sehingga manusia menjadi individu yg seutuhnya. ${ }^{49}$

\section{2) Kerja Adalah Amanah: Bekerja Penuh Tanggung Jawab}

Kerja menurut Alkitab merupakan kerangka utama dari eksistensi manusia ketika ia diciptakan, sebagaimana dikemukakan dalam Kejadian 2:15; "Tuhan Allah mengambil manusia itu dan menempatkannya dalam taman Eden

\footnotetext{
${ }^{47}$ Jansen Sinamo, Op.Cit., 20.

${ }^{48}$ Geertz dan Abdullah Taufik, Agama, Etos Kerja dan Perkembangan Ekonomi (Jakarta: LP3ES, 2008), 25-28.
}

untuk mengusahakan dan memelihara taman itu." Kerja dalam konteks ini adalah amanah dari Allah sendiri. ${ }^{50}$

\section{3) Kerja adalah panggilan}

Panggilan adalah konsep yang sangat tua, sangat klasik. Sering juga disebut sebagai darma, kewajiban luhur, atau tugas sakral untuk mengerjaka sesuatu. Oleh filsuf Immanuel Kant yang dikutip oleh Jansen Sinamo menyebutkan bahwa kesadaran akan panggilan suci itu disebut kesadaran moral. ${ }^{51}$

Kerja Adalah Aktualisasi: Aku Bekerja Keras Penuh Ketelatenan dalam beraktualisasi dan mengembangkan diri melalui kerja, seseorang harus memilki visi yang menjadi tujuan dan panduannya dalam beraktualisasi. Bagi pekerja Kristen jelaslah visi tersebut harus diyakini sebagai sesuatu yang datangnya dari Allah. Apapun yang menjadi cita-cita dan hasrat yang terkadang dalam batinnya, yang kemudian diaktualisasikan lewat kerja, harus diimani sebagai visi Allah bagi dirinya.

Kerja Adalah Ibadah: Aku Bekerja Dengan Cinta Penuh Bakti dan Dedikasi Ibadah berarti mengabdi kepada Tuhan secara total, ketika bangun maupun tidur, ketika ramai ataupun sendiri. Kerja memang ibadah atau bisa juga sebentuk ibadah. Kita beribadah di dua tempat, pertama di gedung peribadatan, kedua di tempat kerja. Orang yang tidak mampu melihat keagungan di dalam, di balik, dan di ujung pekerjaannya hanya akan sering mengeluh dan tidak pernah mensyukuri keadaannya. Penghayatan kerja sebagai lapangan kembalinya roh kerja ke dalam pekerjaan dan tempat kerja kita.

\footnotetext{
${ }^{49}$ Ibid,. 108.

${ }^{50}$ Jansen Sinamo, Op.Cit., 126.

${ }^{51}$ Ibid., 145.
} 
Kerja adalah seni: Aku bekerja Kreatif Penuh Estetika Kerja sebagai seni yang mendatangkan kesukaan dan gairah kerja bersumber pada hal yang kreatif. Aktivitas seni menuntut pengguna potensi kreatif dalam diri baik untuk menyelesaikan masalah kerja yang timbul maupun untuk menggagas hal yang baru Menurut Budihardjo Gairah kerja dapat dilihat dari (1) hasil pekerjaan adalah buah yang manis yang menyukakan hati, (2) pekerjaan menyediakan status social (3) pekerjaan menyediakan identitas pikis yang penting, (4) pekerjaan menyediakan aktivitas yang terstruktur, terpola, dan teratur, (5) pekerjaan menyediakan tantangan yang membuat kita merasakan sense of accomplishment, (6) pekerjaan menyediakan aktivitas kreatif, artistik, dan estetik. $^{52}$

Kerja Adalah Kehormatan: Aku Bekerja Tekun Penuh Kualitas dan Keunggulan Kerja sebagai kehormatan memiliki sejumlah dimensi yang sangat kaya. Pertama, secara okupasional, pemberi kerja menghormati kemampuan kita dengan memilih kita sebagai yang layak memangku jabatan atau melaksanakan tugas tersebut. Kedua, secara psikologis, pekerjaan memang menyediakan rasa hormat diri bagi kita yang tumbuh dari kesadaran bahwa kita mampu sehingga melahirkan kebanggan dan harga diri yang sehat. Inilah rasa hormat diri (self-respect). Ketiga, secara sosial, kerja memberikan kehormatan karena berkarya dengan kemampuan diri sendiri adalah kebajikan. Keempat, secara finansial, pekerjaan memampukan kita membiayai diri secara ekonomis. Kelima, secara moral, kehormatan berarti kemampuan menjaga perilaku etis dan menjauhi perilaku nista. Keenam, secara

\footnotetext{
52 Budihardjo, Etos Kerja (Jakarta: Gramedia Pustaka Utama, 2001), 68.

${ }^{53}$ Jansen Sinamo, Op.Cit., 307-308.
}

personal, jika pengertian moral dapat dipenuhi maka kehormatan juga berarti kepercayaan. Ketujuh, secara profesional, kehormatan berarti prestasi unggul (superior performance), kinertja dan prestasi yang baik membuat kita dikagumi dan di hormati orang.

Kerja Adalah Pelayanan: Aku Bekerja Paripurna Penuh Kerendahan Hati Apapun pekerjaan kita bila kita renungi sesungguhnya eksis untuk melayani. Melalui pekerjaannya manusia memuliakan Tuhan, bangsa dan negara, serta keluarga. Berhadapan dengan kemuliaan seharusnya kita bersikap lebih rendah hati dan melayani dengan segenap rasa hormat. Disisi lain pelayanan adalah sikap mulia. 53 Kamus Webster menjelaskan bahwa kata mulia memiliki lima makna sebagai berikut: ${ }^{54}$ (a) Status kelahiran dari ningrat (b) Karakter yang hebat (c) Sifat stabil dan tidak mudah rusak (d) Terkenal dan ternama (f) Kualitas tinggi, luar biasa dalam penampilan.

\section{Metode Penelitian}

Penelitian ini adalah penelitian dengan pendekatan penelitian kualitatif yang bersifat deskriptif. Pendekatan yang digunakan dalam penelitian ini adalah pendekatan kualitatif yang bertujuan untuk mendapat gambaran secara detail mengenai hal-hal yang akan diteliti. Menurut Moleong, penelitian kualitatif adalah penelitian yang bermaksud untuk memahami fenomena tentang apa yang dialami oleh subjek penelitian, misalnya: perilaku, persepsi, motivasi, tindakan, dan lain-lain, secara holistik, dan dengan cara deskripsi dalam bentuk kata-kata dan bahasa pada suatu konteks khusus yang

\footnotetext{
${ }^{54}$ Mayang Sari Lubis, Metodologi Penelitian (Yogyakarta: Budi Utama, 2018), 10.
} 
alamiah dan dengan memanfaatkan berbagai metode alamiah. ${ }^{55}$ Moleong juga mengutip pendapat Bogdan dan Taylor yang mendefinisikan bahwa penelitian kualitatif merupakan prosedur penelitian yang menghasilkan data deskriptif berupa kata-kata tertulis maupun lisan dari orangorang dan perilaku yang diamati. ${ }^{56}$ Dengan menggunakan pendekatan ini, maka penelitian tentang desain kurikulum Pendidikan agama Kristen untuk ibadah yang berorientasi pada etos kerja bagi pegawai pemerintah di Balai Kota Propinsi DKI Jakarta dapat berjalan dengan baik.

Teknik pengumpulan data dalam penelitian ini adalah tinjauan pustaka dan wawancara. Tinjauan Pustaka adalah kegiatan untuk mengumpulkan data-data berupa informasi dari buku-buku, jurnal, majalah, dokumen dan literatur lainnya yang bermanfaat untuk menyusun landasan teoritis sebagai tolak ukur dalam menganalisis penelitian lapangan. Mayang Sari Lubis mengutip pendapat Made Wirarta bahwa tinjauan pustaka selayaknya menggunakan sumber-sumber terbaru, sumber-sumber yang relevan, banyak dan berbobot. ${ }^{57}$ Berdasarkan penjelasan tersebut, peneliti berupaya mencari sumber-sumber yang relevan dengan penelitian ini. Adapun sumbersumber yang digunakan dalam penelitian ini adalah buku-buku tentang Desain Kurikulum PAK, Ibadah, dan Etos Kerja Kristen.

Wawancara menurut KBBI adalah tanya jawab peneliti dengan manusia sumber (narasumber). Wawancara yang dilakukan peneliti menggunakan tiga pendekatan, yaitu 1) wawancara percakapan informal; 2) wawancara umum; dan 3) wawancara terbuka yang dibakukan. Ketiga pendekatan ini

55 Lexy J. Moleong, Metodologi Penelitian Kualitatif (Bandung: Remaja Rosda Karya, 2014), 4. dikombinasikan untuk memperoleh data yang diharapkan. Ada pun mekanisme yang dilakukan peneliti dalam pengumpulan data melalui wawancara adalah peneliti mewawancarai informan atau narasumber/sumber data yang representatif, kemudian data wawancara diolah untuk mendapatkan hasil. Hal-hal yang ditanyakan adalah sekitar pemahama pegawai tentang kurikulum Pendidikan agama Kristen untuk ibadah yang berorientasi pada etos kerja bagi pegawai pemerintah di Balai Kota Propinsi DKI Jakarta.

Penelitian ini dilakukan di Balai Kota Propinsi DKI Jakarta. Keselurahan jumlah populasi adalag 213 pegawai Kristen Pemerintah di Balai Kota prpinsi DKI Jakarta, sedangkan sampelnya adalah 10 orang yakni terdiri dari 5 pengurus ibadah dan 5 peserta ibadah. Dalam penelitian ini Teknik analisis dibagi dalam tiga tahapan aktivitas yaitu:

- Data Reduction (Reduksi Data) suatu kegiatan yang dilakukan untuk merangkum, memilih hal-hal yang pokok, memfokuskan pada halhalyang penting dicari tema dan polanya dan membuang yang tidak perlu. Hal ini perlu dilakukan mengingat cukup banyaknya data yang diperoleh di lapangan.

- Data Display (Penyajian Data) kegiatan ini dilakukan untuk mempemuda peneliti untuk melihat gambaran secara keseluruhan atau bagian- han tertentu dari data penelitian untuk dapat mengambil kesimpulan yang tepat.

- Conclusion Drawing/Verification (Penarikan Kesimpulan/Verifikasi).

Setelah data-data di reduksi, kemudian dilakukan data display,

\footnotetext{
${ }^{56}$ Ibid., 5.

${ }^{57}$ Mayang Sari Lubis, Op.Cit., 10.
} 
peneliti selanjutnya menarik kesimpulan sesuai dengan hasil penelitian. Menurut Sugiono, kesimpulan yang diperoleh dari datadata yang dianalisis belum tentu dapat menjawab rumusan masalah yang dirumuskan sejak awal, ada kemungkinan berbeda atau tidak sama. Hal ini terjadi karena masalah dan rumusan masalah dalam penelitian kualitatif masih bersifat sementara dan dapat berkembang setelah penelitian di lapangan.

\section{Temuan Penelitian dan Analisis}

\section{Lokasi Penelitian}

Ibadah yang berlangsung setiap hari Jumat di Balai Kota, dilakasanakan oleh Satuan Pelaksana Olahraga, Seni, Budaya, Mental dan Rohani Sekretariat Dewan Pengurus Korpri, di mana Dewan Pengurus Korpri dipimpin oleh Badan Kepegawaian Daerah (BKD) Propinsi DKI Jakarta, yang beralamat di Jalan Merdeka Selatan Nomor 8-9 Blok G Lantai 23 Balai Kota Kelurahan Gambir Kecamatan Gambir Kota Administrasi Jakarta Pusat

\section{Deskripsi Data}

\section{a. Data Wawancara Dengan Pengurus Ibadah.}

Pada bagian ini, penulis melaporkan hasil wawancara terhadap para pengurus ibadah yang berjumlah 5 orang.

\section{1) Pemahaman Kurikulum Pendidikan Agama Kristen}

Pengurus ibadah perlu memahami apa itu kurikulum. Hal ini dibutuhkan supaya para pegawai memahami betapa pentingnya kurikulum. Makna kurikulum dipahami hampir merata oleh pengurus ibadah, yaitu sebagai bahan acuan yang disusun berdasarkan kebutuhan peserta ibadah serta acuan untuk menerapkan sebuah teori yang penerapannya dapat dilakasankan dengan baik. Penerapan dalam hal ini ialah adanya tatanan yang tersusun dengan baik agar sesuai dengan visi misi terselenggaranya ibadah yang mengacu pada kurikulum Pendidikan Agama Kristen. Pendidikan Agama Kristen ialah Pendidikan yang mampu menyampaikan dan mengajarkan nilainilai Kristen yang ada di dalam Alkitab dan bertumbuh serupa dengan Kristus. Disamping itu juga PAK berupaya membawa setiap orang mengenal, memahami dan mengalami kasih dan karya Allah serta rencana-Nya dalam panggilan hidup sebagai orang Kristen yang dapat diperoleh baik dalam keluarga, gereja, sekolah dan masyarakat yang pada ahkirnya mampu menjadi saksi Kristus dimana pun berada.

Semua para pengurus ibadah menganggap sangat perlu adanya sebuah kurikulum dalam ibadah. Dengan adanya kurikulum PAK dalam ibadah mampu memenuhi kebutuhan para pegawai, sehingga menghasilkan pegawai yang mampu menciptakan nilai-nilai Kristen dalam bekerja. Menurut para pengurus ibadah kurikulum PAK dalam ibadah itu memiliki fungsi untuk membawa seluruh peserta ibadah masuk dalam panggilan yang hakiki dalam bekerja, sehingga mampu menghadirkan kasih Allah dalam bekerja lewat integritas yang dimiliki oleh setiap peserta ibadah.

\section{2) Pemahaman Ibadah}

Para informan mengatakan bahwa ibadah adalah persekutuan kepada Allah, dan ibadah juga merupakan cara kita untuk menyampaikan rasa syukur kepada Allah. Ibadah yang berlansung di Balai Kota 
terdiri dari beberapa unsur: (1) doa. bagi informan doa adalah menaikkan doa kepada Tuhan adalah cara kita mengenal kehendak-Nya, walaupun sebelum kita meminta Bapa sudah tahu apa yang menjadi kerinduan anak-Nya. (2) Nyanyian. Para informan mengatakan sikap yang benar ketika bernyanyi dengan menaruh pikiran, perasaan dan hati kita kepada Tuhan. (3) Firman Tuhan. Para informan mengatakan bahwa Firman Tuhan itu menegur, menguatkan juga menghiburkan hati. (4) persembahan. Para informan mengatakan memberikan persembahan dengan cara hati yang tulus dan penuh syukur. (5) perjamuan kudus. mengatakan perjamuan kudus ialah suatu peringatan terhadap perjamuan makan malam terakhir Tuhan Yesus kepada murid-muridNya dan perjamuan kudus adalah peringatan akan kematian Tuhan Yesus Kristus.

\section{3) Pemahaman Etos Kerja Kristen}

Para informan mengatakan bahwa etos bekerja adalah amanah, bekerja adalah kehormatan, bekerja adalah pelayanan, bekerja adalah panggilan, bekerja adalah ibadah, bekerja adalah seni, bekerja dengan cinta, bekerja dengan kreatif dan inovatif, dan memiliki visi dalam bekerja. (1) bekerja adalah amanah. para informan mengatakan kerja adalah amanah yaitu bekerja dengan menjalankan perintah yang diberikan kepada kita dengan bertanggung jawab dengan apa yang menjadi beban dan tanggung jawab kita serta bekerja dengan nilai-nilai keyakinan iman kita dan dapat memenuhi amanah dari si pemberi kerja. (2) bekerja adalah kehormatan. Para informan mengatakan bahwa bekerja dengan cara memberikan waktu, pikiran kita kepada pekerjaan yang kita emban, dan bekerja dengan memberikan karya sehingga, kita sendiri mampu menghormati apa yang menjadi tugas kita. (3) para informan mengatakan kerja adalah pelayanan.kerja adalah pelayanan artinya bekerja untuk melayani orang lain, sebagaimana Yesus sudah terlebih dahulu melayani kita tentunya. (4) memiliki visi dalam bekerja. Para informan mengatakan visi mereka ialah memberikan pelayanan yang terbaik kepada masyarakat dan melaksanakan amanah dari si pemberi kerja dengan sebaik-baiknya. (5) kerja adalah panggilan. Para iforman mengatakan kerja adalah panggilan yaitu melakukan tugas dan tanggung jawaban dengan sungguhsungguh. (6) Kerja adalah ibadah. Para informan mengatakan kerja adalah ibadah yaitu Ora et Labora yang artinya bekerja dan berdoa. (7) bekerja dengan cinta. Para informan mengatakan bekerja dengan cinta yaitu caranya kita bekerja dengan setulus hati, tidak menggerutu dan pastinya bermanfaat bagi orang lain. (8) bekerja dengan kreatif dan inovatif. Para informan mengatakan bekerja dengan kreatif dan inovatif yaitu caranya terus membuka diri dengan hal-hal yang baru, misalnya update dengan berita yang ada, berpakaian rapi, mendesain tata letak meja di kantor.

\section{b. Data Wawancara Dengan Peserta Ibadah}

\section{1) Pemahaman Ibadah}

Para informan mengatkan bahwa ibadah terdiri dari beberapa unsur yaitu nyanyian atau puji-pujian, sikap pujipujian dan nyanyian yang benar, doa, pentinnya doa dalam ibadah, Firman Tuhan, pentingnya Firman Tuhan dalam ibadah, perjamuan, pentingnya perjamuan dalam ibadah, persembahan, dan pentingnya persembahan dalam ibadah. (1) nyanyian atau puji-pujian. Para informan mengatakan adanya nyanyian 
dan puji-pujian kepada Allah itu mengingatkan kita akan kebesaran Tuhan. (2) sikap bernyanyi yang benar dihadapan Tuhan. Pemahaman para informan tentang sikap bernyanyi yang benar di hadapan ialah ketika kita sungguh-sungguh dalam menaikkan pujian kepada Tuhan. (3) Doa. Para informan mengatakan mengatakan doa ialah adalah nafas orang kristen, artinya doa itu adalah hal yang utama dalam hidup. (4) pentingnya doa dalam ibadah. para informan mengatakan penerapan dalam doa sangat penting karena doa adalah nafas hidup orang percaya. (5) pentingkah Firman Tuhan dalam ibadah. Para informan mengatakan bahwa, Firman Tuhan itu merupakan bekal, supaya iman lebih bertumbuh dan mendapat kekuatan dikala lemah. (6) perjamuan kudus. Para informan mengatakan perjamuan kudus yaitu perjamuan Kudus adalah peringatan akan kematian Tuhan Yesus Kristus. (7) Penerapan perjamuan kudus dalam ibadah. informan mengatakan tentang perjamuan kudus yaitu bagi mereka tidak perlu karena waktu sangat terbatas. (8) memberikan persembahan. Para informan mengatakan memberikan persembahan merupakan kewajiban orang Kristen. (9) cara memberikan persembahan pada Tuhan. para informan tentang cara memberi persembahan kepada Tuhan yaitu, memberikan persembahan dengan hati yang tulus dan penuh syukur.

\section{2) Etos Kerja Kristen}

Para informan mengatakan bahwa bekerja adalah amanah, belerja adala kehormatan, bekerja adalah pelayanan, bekerja adalah panggilan, bekerja adalah ibadah, bekerja adalah seni, bekerja dengan cinta, bekerja dengan kreatif dan inovatif, dan memiliki visi dalam bekerja. (1) kerja adalah amanah. Para informan mengatakan kerja adalah amanah yaitu kerja dengan rasa tanggung jawab, karena menyadari kerja itu ialah titipan Tuhan. (2) Kerja adalah panggilan. Para informan mengatakan kerja adalah amanah yaitu menjaga jam kerja untuk kepentingan pekerjaan, artinya mengutamakan pekerjaan terlebih dahulu. (3) cara melaksanakan panggilan.Para informan mengatakan bahwa melakasanakan panggilan tersebutdengan cara tidak menunda-nunda pekerjaan dan bekerja dengan sepenuh hati. (4) bekerja adalah kehormatan. informan memberikan jawaban bahwa ya kerja adalah sebuah kehormatan. (5) kerja adalah ibadah. Para informan mengatakan bahwa kerja adalah ibadah yaitu bekerja dengan sepenuh hati dan bekerja dengan menyadari bahwa apa saja yang kita lakukan untuk memuliakan Tuhan. (6) bekerja dengan cinta penuh bukti dan dedikasi. Para informan mengatakan bahwa bekerjalah seolah-olah besok tidak ada kesempatan untuk bekerja. (7) kerja adalah pelayanan. Para informan mengatakan bahwa kerja adalah pelayanan yaitu bekerja untuk memberikan dampak bagi orang lain. (8) kerja adalah rahmat. Para informan mengatakan bahwa kerja adalah rahmat yaitu bekerja dengan gairah yang tinggi dan bahagia, karena mendapat anugerah yang mungkin orang lain tidak temukan. (9) bekerja dengan kreatif dan inovatif. Para informanmengatakan bahwa caranya terus mengembangkan potensi yang ada dalam diri, lewat membuka diri untuk terus belajar. (10) memiliki visi dalam bekerja. Para informan mengatakan bahwa mereka mempunyai visi dalam bekerja.

\section{Analisis Data}

\section{a. Tidak ada Penerapan Kurikulum PAK dalam Ibadah}

Pengurus memahami kurikulum tetapi tidak ada penerapan kurikulum PAK 
dalam ibadah, hal ini dikarenakan tidak ada yang bisa mendasain kurikulum PAK. Dalam hal ini, mereka tidak memiliki keahlian untuk mendesain kurikulum PAK sehingga selama ini tidak ada penerapan kurikulum PAK dalam ibadah, mereka juga bukan dari latar belakang Teologi dan PAK, dan bagi mereka penerapan kurikulum PAK dalam ibadah itu tidak penting karena kurikulum PAK itu hanya bisa diterapkan di sekolah dan gereja. Menurut Collin J Marsh dan George Willis, kurikulum adalah semua pengalaman yang didapatkan oleh pembelajar dalam tanpaan hidup. ${ }^{58}$ Artinya kurikulum itu tidak hanya terbatas di sekolah atau gereja saja tetapi bisa diterapkan pada semua aspek kehidupan masayarakat dalam hal ini bisa diterapkan pada gereja, sekolah dan organisasiorganisasi Kristen lainnya. Hal ini sejalan dengan pendapat Muhamad Ansyar kurikulum ialah susunan dari rencana pembelajaran yang diterapkan sebagai pengalaman belajar. ${ }^{59}$ Dalam hal ini, kurikulum berupaya untuk hadir dalam setiap proses belajar mengajar yang bisa diperoleh melalui pendidikan formal atau nonformal.

Dalam hal ini, kurikulum PAK sangat penting untuk diterapkan dalam ibadah yang berlansung di Balai Kota Propinsi DKI Jakarta. Dalam mendesain kurikulum ibadah, harus sesuai dengan kurikulum PAK karena kurikulum PAK merupakan kurikulum yang berpusat pada Alkitab. Lois E. Lebar menyatakan kurikulum yang berorientasi pada Alkitab sebagai kegiatan-kegiatan yag berkaitan

\footnotetext{
${ }^{58}$ Menurut Collin J Marsh dan George Willis, Curriculum Alteenative Approaches (Australia: Education, 2005), 209.

${ }^{59}$ Mohamad Ansyar, Op.Cit., 267.

${ }^{60}$ Lois E. Lebar, Education That Is Christian Proses Belajar Mengajar Kristiani dan Kurikulum yang Alkitabiah (Jawa Timur: Gandum Mas, 2006), 307.
}

dengan isi berotoritas yang dibimbing atau dilaksanakan oleh pemimpin Kristen agar dapat membawa para siswa satu langkah lebih dekat kepada kedewasaan di dalam Kristus. ${ }^{60}$ Dalam mendesain kurikulum PAK di ibadah harus sesuai dengan kondisi dan kebutuhan yang ada sehingga sehingga dapat menjawab kebutuhan sesuai dengan yang diharapkan dan dapat memberi dampak positif dalam peningkatan rohani bagi pegawai Kristen yang ada di balai kota propinsi DKI Jakarta. Menurut Robert W. Pazmino, Kurikulum adalah konten yang disediakan bagi peserta didik dalam pengalaman pembelajaran mereka yang aktual yang dipandu oleh seseorang pengajar. Implementasinya ialah pengajar harus tanggap dengan tanggung jawabnya dalam menyampaikan konten, dan pemgalaman saat merencanakan, mengimplementasikannya, dan mengevaluasi pengajarannya.

Tantangan bagi penyusunan kurikulum adalah menggabungkan konten Krisetn dan pengalaman sehingga pikiran dan kehidupan peserta didik akan dipengaruhi dan diubahkan oleh kebenaran Allah. ${ }^{61}$ Untuk itu, kurikulum PAK harus diterapkan pada ibadah pegawai Kristen di Balai Kota Propinsi DKI Jakarta karena kurikulum PAK sangat penting untuk diterapkan dalam ibadah sehingga ibadah menjadi teratur, menjawab kebutuhan dan kondisi yang ada, dan dapat meningkatkan kebutuhan secara rohani bagi para pegawai Kristen.

61 Robert W. Pazmino, Fondasi Pendidikan Kristen: Sebuah Pengantar dalam Perspektif Injil (Bandung: STT Bandung dan BPK Gunung Mulia, 2012), 323. 


\section{b. Ibadah yang Monoton}

Keterlibatan pengurus dan peserta ibadah selama ini dalam pelaksanaan ibadah yang berlangsung setiap hari Jumat di Balai Kota propinsi DKI Jakarta, mereka menyatakan bahwa selama ini ibadah sudah berlangsung dengan baik. Namun mereka memahami bahwa selama ini dalam pelaksanaan ibadah sangat monoton dan pengajaran dalam ibadah tersebut tidak berakar sehingga tidak menjawab kebutuhan dan kondisi yang ada. Dalam hal ini, pengajaran Firman Tuhan, puji-pujian, doa, dan persembahan dalam ibadah tidak dapat memberikan peningkatan secara rohani bagi para pegawai kristen yang ada di Balai Kota Propinsi DKI Jakarta sehingga ibadah itu mereka menganggap sebagai sebuah rutinitas. Rasid Rachman menunjukan bahwa dalam ibadah terdiri dari aksi dan selebrasi. Sebagai aksi, ibadah bukan hanya sekedar sebuah upacara, hal ini terkait dengan perkataan Paulus dalam Roma 12:1 yang menyatakan bahwa ibadah yang sejati ialah mempersembahkan tubuhmu sebagai persembahan yang hidup, yang kudus, dan yang berkenan kepada Allah, sehingga ibadah bukan hanya sebagai sebuah upacara. ${ }^{62}$

Menurut David R. Ray, G, ibadah sebagai sebuah selebrasi atau aturanaturan upacara yang ditentukan oleh suatu agama, dan ini penting menjadi dasar untuk menghantarkan jemaat pada sebuah aksi. Ibadah dalam kekristenan ditekankan pada umum dan inklusif bagi berbagai peristiwa (ritual-ritual) yang menegaskan kehidupan ketika gereja merayakan pertemuan bersama guna mengekspresi-

${ }^{62}$ Rasid Rachman, Pembimbing Ke dalam Sejarah Liturgi (Jakarta: BPK Gunung Mulia, 2010), 1. kan iman mereka (liturgi) dalam pujipujian, mendengarkan Firman Allah, dan merespons kasih Allah dengan berbagai karunia dari kehidupan mereka. ${ }^{63}$

Dalam pelaksanaan ibadah selama ini di balai kota propinsi DKI Jakarta, dalam susunan liturginya juga tidak teratur dengan baik sehingga membuat ibadah itu monoton dan membosankan. Dalam hal ini, dalam menentukan tema khotbah tidak sesuai dengan kondisi dan kebutuhan yang ada karena tema khotbah di tentukan oleh pembicara, tema khotbah di ulang-ulang, pengkhotbah atau pembicara tidak memiliki wawasan Teologi yang luas, puji-pujian yang dinyayikan tidak sesuai dengan tema khotbah, doa dalam doa safaat tidak ada pokok doa secara khusus bagi para pegawai dan tidak ada kesaksian pujian seperti vocal grup dan paduan suara.

Menurut David R. Ray, Ibadah yang berbentuk upacara merupakan bagian dasar dari umat Kristen, yang di dalamnya ibadah menggunakan liturgi. Untuk jelasnya liturgi adalah sehimpunan katakata atau gerakan, atau simbol, atau sebuah pengingat akan hal-hal yang sering kita lupakan, atau memiliki suatu kekuatan yang dapat mengantarkan kita melampaui realitas. Liturgi dalam ibadah memberikan cara untuk mengekspresikan iman kita melalui tindakan nyata yang kita lakukan. ${ }^{64}$ Sedangkan menurut J. L. Ch. Abineno liturgi lebih dikenal luas oleh banyak orang sebagai sebuah urutan dan aturan dari sebuah ibadah, sehingga dalam ibadah itu sendiri dibentuk oleh unsur-unsur yang umum dan tetap. Adapun unsur-unsur liturgi adalah Votum, Salam, Introitus, Pengakuan dosa, Pemberitaan Anugerah dan Hukum, Gloria Kecil, Kyrie Eleison,

\footnotetext{
${ }^{63}$ David R. Ray, Gereja yang Hidup; Ide-ide Segar Menjadikan Ibadah Lebih Indah (Jakarta: BPK Gunung Mulia, 2009), 9.

${ }^{64}$ Ibid., 7.
} 
dan Nyanyian Pujian, Doa, Pembacaan Alkitab, Kotbah, Mazmur, Haleluya, Pengakuan Iman, Doa Syafaat, Pemberian Jemaat, Nyanyian Jemaat, Paduan Suara dan Berkat. ${ }^{65}$

Dalam pelaksanaan ibadah pegawai Kristen di Balai Kota Propinsi DKI Jakarta para pengurus ibadah harus memahami bahwa liturgi memiliki peranan yang sangat penting dalam ibadah, untuk itu para pengurus ibadah dalam menyusun liturgi ibadah harus sesuai dengan kondisi yang kebutuhann yang ada. Dalam hal ini, dalam menyusun liturgi mereka yang harus menentukan tema khotbah, menentukan pengkhotbah yang memiliki latar belakang Teologi yang jelas dan memiliki pemahaman Teologi yang luas, memilih puji-pujian yang berkaitan dengan tema khotbah sehingga suasana ibadah tidak terkesan monoton dan membosankan serta mereka tidak menganggap ibadah itu hanya sebua rutinitas saja.

Dalam pelaksanaan ibadah, para pengurus harus benar-benar menyusun liturgi itu secara kreatif dan sistematis sehingga suasana ibadah itu dapat memberikan suasana yang dimana para pegawai benar-benar merasakan hadirat Tuhan dan membawa mereka untuk mengalami perjumpaan secara pribadi dengan Tuhan, serta mencapai tujuan bersama yang diharapkan yaitu mereka memiliki peningkatan secara rohani dalam kehidupan dan juga berdampak bagi pegawai-pegawai lain yang ada di Balai Kota Propinsi DKI Jakarta.

65 J. L. Ch. Abineno, Unsur-Unsur Liturgia yang Dipakai Gereja-gereja di Indonesia (Jakarta: BPK Gunung Mulia, 1999), 111-113.

\section{c. Tidak Ada Hubungan Antara Kerja dan Ibadah}

Para pegawai Kristen di Balai Kota Propinsi DKI Jakarta, selama ini mereka mengganggap bahwa kerja itu tidak ada hubungannya dengan ibadah. Dalam hal ini, bagi mereka kerja itu yaitu bekerja untuk mendapatkan upah dan juga kerja itu menyelesaikan pekerjaan yang diperintakan oleh pimpinan jadi kerja itu tidak ada hubungannya dengan ibadah. Sebagai pegawai Kristen dalam bekerja mereka tidak memahami bagaimana memiliki etos kerja kristen yang baik dalam bekerja sehingga mereka menggangap pekerjaan itu adalah sebuah rutinitas biasa, bekerja untuk mencapai prestasi, mereka bekerja untuk menyenangkan hati pimpinan. Hal ini sangat bertentangan dengan pengajaran Kristen, dalam pengajaran Kristen bekerja adalah ibadah, bekerja adalah melayani dan bekerja panggilan. Menurut Eka Darmaputra menjelaskan bahwa doa tidak dengan sendirinya bermakna daripada kerja, sebab kerja pun dapat dilihat sebagai doa. ${ }^{66}$

Jadi makna ora et labora sejatinya adalah berdoa adalah bekerja, sebab berdoa yang benar adalah bekerja dengan penuh tanggung jawab serta displin sedangkan bekerja dengan penuh tanggung jawab dan disiplin merupakan doa dan ibadah kepada Tuhan. Dalam hal ini, dalam bekerja para pegawai Kristen di Balai Kota Propinsi DKI Jakarta harus memhami bahwa kerja itu tidak hanya untuk mendapat upah, tidak hanya menyelesaikan pekerjaan yang di perintahkan oleh pimpinan, kerja itu tidak hanya untuk mendapatkan prestasi, dan kerja itu tidak hanya untuk menyenangkan

\footnotetext{
${ }^{66}$ Eka Darmaputra, Op.Cit., 111.
} 
hati pimpinan tetapi bekerja itu ada hubungannya dengan ibadah. Menurut Janse Sinamo, bekerja adalah rahmat, bekerja adalah ibadah, bekerja adalah panggilan, bekerja adalah kehormatan, bekerja adalah amanah, bekerja adalah aktualisasi, dan kerja adalah seni. ${ }^{67}$

Dalam bekerja para pegawai Kristen harus memahami bahwa bekerja adalah ibadah. Untuk itu mereka harus bekerja dengan dengan tulus, bekerja dengan penuh tanggung jawab, bekerja dengan sungguh-sungguh, bekerja bukan hanya untuk menyenangkan hati pemimpin tapi juga bekerja untuk kemuliaan Tuhan. Dalam hal ini, ketika mereka bekerja dengan sungguh-sungguh dan bertanggung jawab maka mereka akan memiliki etos kerja Kristen yang baik dan menjadi teladan bagi pegawai lain. Selain itu, ketika mereka memahami bahwa kerja adalah ibadah, maka dalam bekerja mereka harus mengaplikasikannya dengan cara bekerja dengan penuh tanggung jawab, melayani orang lain dengan tulus, menghargai pimpinan, membantu dan menolong sesama pegawai dalam bekerja, dan menjadi contoh dan teladan yang baik bagi orang lain dalam bekerja.

Berdasarkan hasil analisis penulis, penulis memberikan sebuah Desain Kurikulum Pendidikan Agama Kristen untuk Ibadah yang Berorientasi Pada Etos Kerja Kristen Bagi Pegawai Pemerintah di Balai Kota Propinsi DKI Jakarta selama tiga bulan yakni dimulai dari bulan Oktober sampai Desember 2019.

\section{E. Kesimpulan}

Berdasarkan hasil penelitian, informan sudah memahami apa itu desain kurikulum Pendidikan Agama Kristen. Hal

\footnotetext{
${ }^{67}$ Jansen Sinamo, Teologi Kerja Modern dan Etos Kerja Kristian (Jakarta: Institut Darma Mahardika, 2011), 112.
}

ini terlihat dari pernyataan-pernyataan yang disampaikan pengurus bahwa desain kurikulum Pendidikan Agama Kristen ialah sebuah tatanan, pola atau rencana pembelajaran PAK bagi peserta didik dalam komunitas Kristen, baik di Gereja, sekolah atau masyarakat majemuk yang dibangun di atas Alkitab dan melaluinya peserta didik mengalami pengalaman pertumbuhan rohani sepanjang hidupnya dan bertumbuh serupa dengan Kristus Yesus. Namun sangat disayangkan pemahaman ini hanya sampai teori saja, tidak sampai pada pelaksanaan di lapangan ibadah. Terbukti dalam hasil penelitian ini tidak ditemukan desain kurikulum dalam ibadah yang berlangsung di Balai Kota.

Berdasarkan hasil penelitian, informan sudah memahami yang dimaksud dengan ibadah. Ibadah ialah penyataan diri Allah sendiri dalam Yesus Kristus dan tanggapan manusia terhadapNya yang mencakup baik pelayanan Allah kepada manusia maupun pelayanan manusia kepada Allah yang telah mencapai titik puncaknya dalam intervensi Kristus yang melanjutkan karya penyelamatan-Nya melalui karya Roh Kudus.

Berdasarkan hasil penelitian, informan sudah memahami yang dimaksud dengan etos kerja Kristen. Etos kerja Kristen ialah perilaku kerja positif yang lahir sebagai buah dari keyakinan dan komitmen total pada paradigma kerja tertentu serta keyakinan yang mendalam serta komitmen yang kuat pada nilai-nilai kerja tertentu yang tampak keluar sebagai perilaku kerja yang positif serta bekerja merupakan kesadaran akan panggilan Allah dalam kehidupan manusia sehingga ia harus bekerja efektif, berkualitas serta menghasilkan nilai-nilai Kristiani dalam 
berkerja dan bekerja dengan sepenuh hati dalam rangka melayani Tuhan.

\section{F. Referensi}

Alkitab.

Boehlke. Sejarah Perkembangan Pikiran dan Praktik PAK dari Yohanes Amos Comenist sampai perkembangan PAK di Indonesia, Jakarta: BPK Gunung Mulia, 2010.

Brill, J. Wesley. Tafsiran Surat Ibrani. Bandung: Kalam Hidup, 1973.

Brownlee, Malcolm. Tugas Manusia Dalam Dunia Milik Tuhan: Dasar Theologis Bagi Pekerjaan Orang Kristen Dalam Masyarakat. Jakarta: BPK. Gunung Mulia, 2004.

Budihardjo. Etos Kerja. Jakarta: Gramedia Pustaka Utama, 2001.

Cherry, Constance M. The Worship Architect A Blue Print For Designing Culturally Relevant and Biblically Faitful Service. Grand Rapids: Baker Academic, 2010.

Clark, Robert E., dan Lin Johnson. Christian Education Foundations For The Future. Chicago: Moody Publishers, 1991.

Darmaputra, Eka. Etika Sederhana Untuk Semua: Bisnis, Ekonomi dan Penatalayanan. Jakarta: BPK Gunung Mulia, 2001.

Enklaar, I.H, dan E.G. Homrighousen. Pendidikan Agama Kristen. Jakarta: BPK Gunung Mulia, 2009.

Friere, Paulo dan Ivan Illich. Menggugat Pendidikan - Fundamentalis, Konservatif, Liberal, Anarkis. Yogyakarta: Pustaka Pelajar, 2015.

GP, Harianto. Pendidikan Agama Kristen dalam Alkitab \& dunia Pendidikan Masa Kini. Yogyakarta: Andi, 2012.

Groome, Thomas. Christian Religius Education. Jakarta: BPK Gunung Mulia, 2011.

Hamalik, Oemar. Manajemen
Pengembangan Kurikulum.

Bandung: PT. Remaja Rosdakarya, 2007.

Hamzah, Amir. Etos Kerja Guru. Malang: Literasi Nusantara Pendidikan, 2019. Herzberg, Frederick. The Motivation to Work. Routledge: Reprint Edition, 1993.

Homrighausen, E.G. Pendidikan Agama Kristen. Jakarta: BPK Gunung Mulia, 2015.

Iris, Cully. Dinamika Pendidikan Kristen. Jakarta: BPK Gunung Mulia, 2015.

Kristianti, Paulus Lilik. Prinsip dan Praktik Pendidikan Agama Kristen. Yogyakarta: ANDI, 2006.

Lebar, Lois E. Education That Is Christian Proses Belajar Mengajar Kristiani \& Kurikulum Yang Alkitabiah. Jawa Timur: Gandum Mas, 2006.

Lubis, Mayang Sari. Metodologi Penelitian. Yogyakarta: CV Budi Utama, 2018.

Martasudjita, Emanuel Pr. SakramenSakramen Gereja (Tinjauan Teologis, Liturgis, dan Pastoral). Yogyakarta: Kanisius, 2003.

Moleong, Lexy J. Metodologi Penelitian Kualitatif. Bandung: Remaja Rosda Karya, 2014.

Nasution, S. Asas-Asas Kurikulum. Jakarta: Bumi Aksara, 2001.

Nuhamara, Daniel. Pembimbing PAK. Bandung: Jurnal Info Media, 2007.

Nurdin, Syafruddin. Guru Profesional dan Implementasi Kurikulum. Jakarta: Quantum Teaching, 2005.

Pazmino, Robert W. Fondasi Pendidikan Kristen: Sebuah Pengantar dalam Perspektif Injil. Bandung: STT Bandung dan BPK Gunung Mulia, 2012.

Rachman, Rasid. Hari Raya Liturgi: Sejarah dan Pesan Pastoral Gereja. Jakarta: BPK Gunung Mulia, 2005.

Robert W, Pazmino. Fondasi Pendidikan 
Kristen: Sebuah Pengantar dalam Perspektif Injil. Bandung: STT Bandung dan BPK Gunung Mulia, 2012.

Sanjaya, Wina. Kurikulum dan Pembelajaran. Jakarta: Kencana, 2010.

Sanjaya, Wina. Pembelajaran Dalam Implementasi Kurikulum Berbasis Kompetensi. Jakarta: Kencana, 2006

Sanjaya, Wina. Perencanaan dan Desain Sistem Pembelajaran. Jakarta: Kencana, 2008.

Sidjabat, Samuel. Startegi Pendidikan Kristen: Suatu Tinjuan TeologisFilosofis. Yogyakarta: Andi,1996.

Sinamo. 8 Etos Kerja Profesional. Jakarta: Darma Mahardika, 2011.

Sinamo, Jansen H. Etos Kerja Profesional Navigator Anda Menuju Sukses. Jakarta: Spirit Mahardika, 2011.

Sinamo, Jansen. Teologi Kerja Modern dan Etos Kerja Kristian. Jakarta: Institut Darma Mahardika, 2011.

Sugiyono. Metode Penelitian Pendidikan: Pendekatan Kuantitatif, Kualitatif, dan R\&D. Bandung: Alfabeta, 2009.

Sukiman. Pengembangan Kurikulum Perguruan Tinggi. Bandung: PT. Remaja Rosdakarya, 2015.

Sukmadinata, Nana Syaodih. Pengembangan Kurikulum: Teori dan Praktek. Bandung: Rosda Karya, 1997.

Sutanto, Hasan. Homiletik, Prinsip dan Metode Berkhotbah. Jakarta: BPK Gunung Mulia, 2004.

Tanya, Eli. Gereja dan Pendidikan Agama Kristen. Jawa Barat: Sekolah Tinggi Teologi Cipanas, 1999.

White, James F. Pengantar Ibadah Kristen. Jakarta: BPK Gunung Mulia, 2012.

Wyckoff, D. Campbell. Theory and Design of Christian Education Curiculum. Philadelphia, PA: The Westminster Press, 1961.
Undang-Undang, Jurnal, Skripsi

Depdiknas. Undang-Undang RI Nomor 20 Tahun 2003. Jakarta: Depdiknas, 2004.

Kusnan, Ahmad. Analisis Sikap Iklim Organisasi, Etos Kerja Dan Disiplin Kerja Dalam Menentukan Efektifitas Kinerja Organisasi di Garnizun Tetap III Surabaya. Thesis, Surabaya: Universitas Airlangga, 2004.

Simanjuntak, Junihot M. Implikasi Konsep Dan Desain Kurikulum Dalam Tugas Pembinaan Warga Jemaat. Jurnal Jafray Vol. 12 No. 2 Oktober 2014.

Internet

Sejarah terbentuk Ibadah di Pemerintah DKI Jakarta di Balai Kota https://bkddki.jakarta.go.id/berita/re $\mathrm{ad} /$ profiluptbinroh, diakses Jumat 26 Juli 2019 pkl 20.30. 